\title{
Vocational Adult Education and Rural Development in Ekiti State
}

\author{
Mary Adedokun ${ }^{1 *}, \quad$ Gabriel Agboola ${ }^{2} \quad$ Comfort Adeyemo ${ }^{3}$ \\ Department of Adult Education and community Development Faculty of Education, \\ Ekiti State University, Ado-Ekiti
}

\begin{abstract}
The study basically examined whether vocational education had any relationship with rural community development. The descriptive research design of the survey type was used for the study. The population in Ekiti rural communities (adult only) totaled 700620 and 600 respondents were chosen for the study through multistage sampling procedure to select 600 respondents for the study. A self designed instruments tagged vocational educational rural community development was used to collect data and only one hypothesis was generated and tested at 0.05 level of significance making use of Pearson's Product Moment Correlation. The result revealed a significant relationship between vocational education and rural community development at $\mathrm{P}$-value $0.000<$ than 0.05 and at $(\mathrm{r}=0.247)$ which showed that as vocational education increased so does rural community development. Based on the findings, it was recommended that government at all levels should intensify efforts at seeing that every community member is self reliant by encouraging them to acquire one vocational skill or the other and that individuals within communities should be enthusiastic about vocational skill acquisition because it is when they are willing that they can acquire skills successfully.
\end{abstract}

Keywords: vocational skills, education, rural transformation, rural communities, urban communities, development.

DOI: $10.7176 / \mathrm{JEP} / 11-6-15$

Publication date: February $29^{\text {th }} 2020$

\section{Introduction}

Nigeria is a developing country located within the tropical region. Nigeria has few urban communities most of which are interspersed with slums making such less of what real urban cities should look like. In comparison with rural communities, these urban centres have modern infrastructural facilities such as pipe-borne water, good road networks, electricity, communication networks and modern and accessible health care services. The availability of these facilities are in contrast to rural communities where majority of the Nigerian population dwell. In rural communities in Ekiti State, there is scarcity of facilities which makes life boring and sometimes uncomfortable for rural dwellers. The rural communities are characterized by poverty (with people living below $\$ 1$ dollar per day), ignorance for lack of exposure and educational attainment, superstitious beliefs and peasant agricultural activities which could not be sufficient to feed households let alone of having surplus for sales. There is also low level of education that retards modern development (Elebari, Mbadiwe, Woko, Oriode and Kasiowo, 2014).

Mahatma Gandi in Vasudera rao states "If I learn carpentry from an illiterate carpenter ,only I know how to do the work, but if I learn from a literate carpenter, my thoughts will be stimulated." For rural development to become a reality, every rural community member must be made literate as literacy is germane to learning any vocation. This is because according to Vasudeva Rao (2012) national integration and development is only possible with literate persons because illiterate technicians are prone to being exploited by the educated persons who hire their labour leaving much to be desired in terms of their earning for personal and community upgrading and sustainability.

For rural communities to be developed in the real sense of bringing elevated standard of living to the rural population, education in all its ramifications must not be underestimated. This would mean giving them qualitative education, health extension education as healthy people make wealthy and healthy nations, intensive agricultural extension programme since agriculture is the base of rural occupation.. Education is therefore, core to achieving rural development which eventually translates into national development. This is because national resources are being depleted for the sake of industrialized model of development at the expense of rural development though rural population is dependent on natural resources for livelihood. The right of an average rural community dweller can, therefore, enjoy a boost by being vocationally literate.

Ajayi and Afolabi (2009) express strongly that it is through education that a nation can achieve her social, political, moral, cultural and economic aspirations. Through education individuals gain knowledge, skills, character and desirable values that will translate into personal, community and self actualization. Education is therefore, core in making a group of people understand what development is all about and it will help them to play active role in bringing about development to their community. This type of education may be formal or non-formal, the result of which is lifelong learning, adult education unlike formal education is education for life. It is education undertaken with the conscious intention of bringing about changes in information, knowledge, skills appreciation and attitude with the aim of being engaged in critical analysis of issues going on around them, being empowered 
to make decisions that will benefit them and being empowered to identify and solve problems facing them individually or in the community as a whole. Adult education (of which vocational education is an offshoot) aims at bringing out more effective participation in worthwhile values of communities making adult education to be a great socializing agent for rural and urban communities; and through which individuals can acquire skills for earning thereby contributing to rural transformation. (Sagar Reddy,2007)

The rural people, therefore, need to be empowered with various programmes of adult education one of which is vocational adult education. All the programmes of adult education would work together to equip the people with various life skills as there should be a "sandwich" of adult educational programmes in order to reposition rural communities. Life skills is suggestive of people's need to learn to acquire various skills they require to live well in a technological changing world as societies revolve around them (Adedokun, 2019). This implies that vocational adult education cannot be given in isolation of literacy skills. This is because people need to be functional, needing the skills of reading, writing and arithmetic in their various vocations. It is also germane that rural people must be taught healthful living because when the health of the rural people is sound, they are able to perform well in their chosen vocations. There is also the need to enlighten people on the much valued rural vocation which is agricultural practices through agricultural extension programme. Vocational adult education could only achieve the required development in rural community when aspects of these are taught the people.

Vocational education and training is education and training for work and also to improve performance on the job because it is education with practical experience where people make use of their skills, creativity, and innovations for self actualization. It is that education that could make rural as well as urban community members to become self reliant especially in this era of scarce white-collar jobs. Okorie (2001), thus, describes vocational education as that education designed to prepare skill workers for industries, agriculture and commerce.

Vocational education programme plays an essential role in improving the well being of rural dwellers and rural communities because it increases productivity, it empowers individuals to become self reliant and it stimulates entrepreneurial spirit in them. It awakens the hitherto lying potentialities of the rural people while at the same time building strong human resources. Vocational education is tied to strengthening social links of a community through provision of local employment, creativity and sustainable existence.

Vocational education which is sometimes referred to as career and technical education, prepares people to work as technician or as a tradesman or artisan. The vocational adult education may not be taught in formal school setting, it may be in form of apprenticeship in traditional trades such as training in traditional drumming, blacksmithing, hunting and tailoring and trading (en.wikipedia.org/within/vocational-education \# Australia).

The World Bank (2019), World Development Report on the future work emphasized the fact that vocational education is important to enable workers compete in a "changing labour market where technology plays an important role" (np).

Rishi, Shravanth and Venkata (2019) conducted a research on vocational training in India based on determinants of participation and effects on wages. The authors found that unemployment is on the increase and to stem the tide of unemployment, efforts must be made to make employment opportunities available. To this end, they advocated for skill development. They also found in their study that the unemployment rate for vocational graduates was lower than the unemployment rate of general secondary graduates.

Ariagada and Ziderman (1992) also expressed that vocational stream graduates employed in occupations related to their field of study had significantly higher earnings than regular academic graduates in Brazil. This implies that rural youth who are not academically sound should be encouraged to go for vocational education and training be it in form of apprenticeship or through non-formal vocational adult education. This will put them on a sound footing of being self reliant and thereby being able to contribute immensely to the rural community development. Rural adult are not exempted from this type of education in order to raise their standard of living and to be able to take care of their personal and community responsibilities.

Similar research on the importance of vocational education and training was also carried out in Thailand by Moenjak and Warswick (2003), they discovered that a much higher return was found over and above general education at the same level. This points out that developing skills of people whether in rural or urban communities is germane to development.

Explaining further on the importance of vocational education, Eisthorst and Rodiques, Planas, Schmidl and Zimmerman (2015) pointed out that government funded vocational education and training to improve the job opportunities of youth who do not possess the skills demanded by them either in the labour market or for being self reliant. This is also being done in Nigeria through various programmes where government funds various skills development programmes such as National Economic Empowerment and Development Strategy (NEEDS), National Directorate of Employment (NDE) and Youth Enterprise with Innovations in Nigeria.

Adult education programmes of which vocational education is one can, therefore, be perceived as an important tool for transformation of dormant ideas, values, behavioural changes thus, acting as an agent of positive change not only for rural development but for personal and urban development (Vasudeva, Rao, b. s. 2012).

Daro, Greg and Li (2020) were of the opinion that giving rural transformation the needed attention, therefore, 
should be a focus in the relevant vocational education that would develop people's skills and impact rural communities. It is opined that vocational and technical education and training would build the capacities of members to take decisions that would lead to the improvement of their living standard and that the improvement accruing from this would be all round one as there would be transformation socially, politically, culturally, environmentally and health wise. It is when rural members are impacted in all areas that there can be positive change in rural communities as rural transformation is not only about economic transformation as most people think. To UNESCO, UNEVOC, economic development, good as is, can lead to "environmental pollution which can also be hazardous not only to people's health but also lead to depletion of resources on which rural people depend for their livelihood. It could also lead to global warming and climate change" (pg 13).

Though, economic development brings development and change to communities, it is expedient that individuals be armed with knowledge and skills and various capacities to bring about rural as well as personal development. Having necessary coping skills will also enable individuals to adjust to changes accruing in their rural environment. With coping capacities and adjustment mechanisms put in place. Both rural communities and members will develop.

Poverty retards development but when people are in built with vocational skills, abject poverty and its associated negativity like poor education, poor health would be rejected, thus making community members to act in position of bringing changes to their lives.

This act calls for engendering vocational, technical, and training education in people be it formal or nonformal. Children who learn without skills now find earning a living very difficult as white collar jobs are very difficult to come by now but with vocational and technical skills, self reliance with regular and better income is guaranteed thus aiding better living. If the advocated skills development of the World Education Forum in Dakar, Senegal 2000 had been adhered to strictly, there would have been much recorded growth in rural communities all over the world.

World Bank (2008) states that majority of the poor live in rural areas and have nothing to depend on other than agriculture, with resources in excess, however, abundance living would elude them without needed skills and education which would open them to new opportunities in making good use of land for agriculture in modern way and which aids all round sustainability. Giving rural people needed vocational education would provide the required opportunity to acquire skills and knowledge that will lead to development of capacity that will enable rural people to be aware of making right choices in life.

Education that would be provided in Ekiti rural communities must be the type that would meet their needs. This type of education is fully embedded in adult education because it is education that is inclusive. It has the capacity to cater for the needs of both young and old, those that are in one job or the other and the early school leavers. It is education that provides hope for all in their varying capacities. Adult education can thus be viewed as a tool for positive transformational changes to rural communities. Through it ideas and values can be positively changed brining out creativity and initiatives from rural people that can be channeled towards sustainable rural development. The implication is that vocational adult education and training with literacy would go a long way in ensuring sustainability of rural communities and bring about social equity that would eradicate cheating of the poor people by those in high positions of authority.

UNESCO, (2013) states that such skills needed for personal and community transformation are vocational skills that would enable people to engage in self employment and so rural people need better knowledge and skills that would advance them in the practice of agriculture and bring about increased productions.

It is not only vocational education skills that has the capacity of sustaining rural development. Various life skills should be acquired alongside vocational skills to make life better in rural communities. The World Health Organisation (WHO), (1995) in Adedokun (2019) identified the cross cultural areas of life skills which are germane to living qualitative life in any community. Such include, decision making, problem solving skills, creative and critical thinking, communication and interpersonal skills resilience and other coping skills among others. These skills when added to the acquired vocational skills will bring out the best in the community members as these are essential skills for building a healthy society for successful individuals and communities. (British Council, Greece, 2019).

Rhadika (2019), in his article on how adult education can promote rural development submits that for adult education to contribute to rural development, there must be upgrading of adult education programmes with improved teaching and learning methods; explaining fully the concepts of vocations to the adult learners explicitly; making use of technologies and various innovative methods to promote effective learning. The vocational adult education centres should be apt in building into vocational education curriculum necessary skills need in the labour job markets to which the rural learners are being prepare for. Such skills will include personal abilities such as flexibility ,resourcefulness, creativity and communication. This means skills of rural population should be upgraded to generate productivity. Through education rural population will be able to access important information needed to bring about upliftment in their living standards leading to an overall transformation of rural communities. The implication is that of making occupational (vocational education) an essential part of rural 
communities so as to develop knowledge and skills with various economic activities that are in compliance with rural transformation. Doing this will lead to developing vocational skills that will pave way for either better employment opportunities or for better and higher paid jobs.

Lavina (2019) perceives that poverty is a rural phenomenon so also is rural/urban inequalities. These are perceived as obstacles to development that is sustainable, the tide of which could be stemmed down through making rural poor have access to appropriate competencies and skills that would lift the rural population above poverty level.

Rural development was perceived by Mazirow in Oduaran (2008) as efforts that are made to assist rural persons to acquire attitude, skills and concepts for democratic participation in seeking effective solutions to all identified problems. These skills are thus important for rural development as the skills help the rural masses to cope with not only changes in their communities but with changes as they affect their daily living.

In considering vocational education for rural transformation no gender must be left out because female children are often subjected to neglect than male children. Both male and female rural dwellers must be empowered with vocational education so as to be economically empowered thus making them have "voice", think creatively and become active members of communities.

\section{Statement of the Problem}

It has been observed that poverty ravages rural community, that though agricultural practices remain the main source of economy, but such has not been thriving as expected in Ekiti State. It has been observed that when farm work was lagging due to climate change, rural dwellers do not have much to fall back on, thus poverty ravages the people and there is no appreciable development in rural communities. This study, thus, examined whether vocational and technical (adult) education when interjected into rural communities in Ekiti State would lead to rural development with the main question; will vocational education aid rural development in Ekiti State?

\subsection{Purpose of the Study}

The main purpose of this study was to:

1. Investigate the relationship between vocational education programme and rural development in Ekiti State

\subsubsection{Research Hypothesis}

One research hypothesis was generated for the study.

1. There is no significant relationship between vocational education programme and rural development in Ekiti State rural communities.

\section{Methodology}

\subsection{Research Design}

The descriptive research design of the survey type was adopted to determine the relationship between vocational education programmes and rural development. The design was considered appropriate because it focused on the existing situation of rural development and the impact vocational adult education could have on making rural development better in Ekiti state. The survey research studies a small sample from a large population from where inferences are drawn about the characteristics of the defined population.

\subsection{Population}

The population for the study consisted of all adults residing in the rural communities of Ekiti State, which consisted of three Senatorial districts. The population of rural dwellers in Ekiti State according to the National Bureau of Statistics (2019) were 700,620.

\subsection{Sample and Sampling Technique}

The sample for the study consisted of 600 respondents selected from 30 rural communities in Ekiti State using multistage sampling procedure. In stage one, two local government areas were selected from each of the senatorial districts using simple random sampling technique to make a total of six local government areas. Stage two involved the selection of five rural communities from each of the six local government areas used for this study using simple random sampling technique. The last stage was the selection of 20 rural dwellers from each of the 30 selected rural communities making a total of 600 respondents for this study.

\subsection{Research Instrument}

The instrument used for the study was tagged "Vocational Education for Rural Development Questionnaire" (VERDQ). The questionnaire items were raised to elicit information on the importance of vocational education to rural development using 4 points Likert type rating scale of Strongly Agree (SA) 4 points, Agree (A) 3 points, Disagree (D) 2 points and Strongly Disagree (SD)-1 point. 


\subsection{Validity and Reliability}

The instrument was validated by experts in the field of Adult Education and Community Development of the Ekiti State University. The reliability of the instrument was determined through test-retest method. It was administered on 40 respondents outside the study sample within an interval of two weeks, yielding a coefficient value of 0.84 making use of Pearson's Product Moment Correlation Statistics. This coefficient value showed a high degree of reliability.

\subsection{Data Analysis}

The collected data were analyzed by using Pearson's Product Moment Correlation to indicate the relationship/correlation that existed between vocational adult education and rural community development

\subsection{Result and Discussion}

Hypothesis 1: There is no significant relationship between vocational education and rural community development in Ekiti State.

To test this hypothesis, Pearson's Product Moment Correlation statistical tool was used at 0.05 level of significance. Table 1: Vocational Education Programme and Rural Community Development

\begin{tabular}{|l|l|l|l|l|l|}
\hline & Nariables & Mean & SD & R Cal & P value \\
\hline Vocational Education Programme & 600 & 7.44 & 0.85 & & \\
\hline Rural Development & 600 & 102.12 & 5.10 & 0.247 & 0.000 \\
\hline
\end{tabular}
$\mathrm{P}<0.05$

Table 1 shows that P-value $(0.000)$ for the relationship between vocational education and rural community development is less than 0.05 . This indicates a significant relationship between vocational education programme and rural development. The table further shows that there is a positive relationship of $(\mathrm{r}=0.247)$ between vocational education and rural community development. This is an indication that as vocational education improved, rural development also improved.

\subsection{Discussion}

The study found that there was a significant relationship between vocational education and its programmes and rural community development. In conformity with the findings of this study, Sacheti and Sharma (2020) had earlier expressed that technical vocational education and training is essential for development in skilled human resource and they make it clear that the concept of vocational skills training is an old family tradition in India as it is in Nigeria.

The authors submitted that some of the objectives of vocational education programme include: achieving socio economic improvement of the rural areas

(ii) to provide modern facilities and technical knowhow in order to increase the production and per capital income.

Summarily, these authors state that vocational education is critical in rural development because it has great potential in developing human resource for usage and transfer of innovative technologies at the grassroots level and that vocational education has the potential of improving rural areas to achieve overall economic improvement.

The earlier study of Eleberi, Mbadiwe-Woko, Owede, Kosioma (2014) found that rural communities can be transformed through rural industries. These include small and medium scale enterprises (SME). The respondents in the study attested to the fact that vocational education and training which include areas like pottery work, metal work, tailoring, soap making, weaving and hair dressing made them to be economically improved and thereby improving their communities.

To further back the finding, Vasudeva (2012) believes that adult education can be considered as an alternative tool for transformation of ideas, values, behavioural changes, conventions and act as an agent of change. This shows that vocational education being a programme of adult education is very important in rural development.

The finding was also in support of the earlier opinions of Daro, Greg and Li (2020) that vocational education would give the needed capacity to help members of their communities to improve their standard of living.

Rishi, Shravanth and Venkata (2019) in their research carried out in India found that to stem the tide of unemployment (not only in India but worldwide and not only in cities but in rural communities), they advocated skills development. They also found that the unemployment rate for vocational graduates was lower than the unemployment rate of general secondary education. The implication is that with vocational education, people will have skills that would make them productive and thus being able to earn enough for improved living standard.

\section{Conclusion}

The authors examined whether vocational education would have any meaningful impact on rural community 
development. The finding of the study revealed that vocational education is significantly related to rural community development. It was discovered that whether rural population were taken through apprenticeship scheme for vocational skills acquisition (non-formal) or groomed formally, their acquisition of the vocational skills and knowledge would lead to being self reliant and subsequently bring about personal and community improvement. The study also implied that there should be a focus on relevant vocational education that would lead to community development. Vocational skills for rural population should include personal capabilities such as flexibility, resourcefulness, creativity and communication as these skills will enable them access needed information for development . Literacy should, therefore ,be emphasized in the process of preparing rural population for vocational training. When each person in rural community has a vocational skill, earning is guaranteed, poverty can be reduced, good health services accessed and one can also access good and quality educational services as these are indices of development.

\subsection{Recommendations}

The following are recommended.

- That government at all levels should continue to intensify efforts at seeing that people both in rural and urban communities are self reliant through exposure to vocational and technical education and training.

- Government should not only concentrate efforts on training people in urban centres but extend the training efforts and encouragement for self reliance to rural areas no matter how remote they are..

- $\quad$ Those community members who underwent vocational training through the federal government skills acquisition schemes should make efforts to train others in their local government areas so that skill acquisition would reach to the grassroots.

- $\quad$ Every rural community member should make concerted efforts to improve his/her living by having one vocation or the other.

- Self reliance should be encouraged in rural communities so as to overcome poverty.

- Relevant vocational education that are in tandem with the needs of each society should be made available.

\section{Acknowledgments}

Appreciation is due to every author whose document / articles were consulted for this paper

\section{References}

Ajayi, A. I. and Afolabi, F. O. (2009). The role of tertiary education in national development: The Nigerian scenario: Journal of Teacher Education 19(1) 34-46.

Adedokun, M. O. (2019). Life Skills: Implication for community development. Journal of Emerging Trends in Educational Research and Policy Studies.10 (6) 367-373.

Ariagada, A. M and Ziderman, A. (1992). "Vocational Secondary Schooling, Occupational choice and earning in Brazil”. Working Paper Policy. Research Paper No. 1037: Population and Human Resource Department, World Bank, Washington, D. C.

Articles/10.1186/s40461-019-0078-y. accessed 16 January, 2020.

British Council Greece (2019). What are life skills http://www.britishcouncil/gr/en/life skills/about/hat-are-lifeskills. Accessed 20 May, 2019.

Daro- Gavanagh, "Greg-Shaw and Li-Wang (2020). "Technical and Vocational education and training and skills development for transformation" in Revisiting Global Trends in TVE.Unevoc.unesco.org/fileadmin/up/2013_unpub_revisiting_global_trends_in_tvet_chapter9.pdf. Accessed 16 January, 2020.

Eichhorst, W. Rodiques-Planas, N; Schmidl, Zimmerman, K. F. (2015). A roadmap to vocational education and training in industrialized countries. ILR Rev. 68 (2) 314-337.

Elebari, Godwin, Mbadiwe-Woko, Oweda, E. F., Kosioma, E. (2014). Adult Education and Community Development Programmes as vital tool for transformation of rural communities in Nigeria in Journal of Education and Practice, 5(24) 7-12.

Lavinia,G. (2019). Technical and vocational education and training and rural development. Link.springer.com/chapter/10.007\%2F9768-1-4020-5281-1 48. Accessed 16 February 2020

Moenjak, T. and Warswick, C. (2003). Vocational Education in Thailand; A study of choice and returns. Econ.Education Rev. 22, 99-107.

Oduaran, A. B. (2008). An introduction to community development. Benin, Uniben Press.

Okorie, J. V. (2001). Vocational Industrial Education. Owerri: League of Researchers in Nigeria.

Rhadika Kapur (2019).Contribution of adult education in promoting rural development. ACTA Scientific Agriculture. 3(9) 1-6.

Rishi, K. Shravanth, M. and Venkata, S. P. (2019). Vocational training in India: Determinants of Participation and effects on wages. https://ervet-journal.springeropen.com/ Accessed 12 January, 2020. 
Sagar Reddy ,G.V.(2007). Adult Education: A Strategy for Sustainable Rural Development, paper published in "Rural Development Initiations and Empowerment of Weaker Section Practices Promotionand Programmes (ed. vol) Ambala Cantt, The Associated Publishers.

Sacheti, A. K. Sharma, P. S. (1997). Technical and Vocational Education for Rural Development: The case of India In Technical and Vocational Education for rural development. Delivery patterns-studies, No 9.UNEVOC (1997).In www.nzdl.org/gdslmod?c=d-00000-00-off.qcwf-00-0-0-10-0-0-0direct-10-4-0-1111-en-50-20-abc.en.

UNESCO (2013). Revisiting Global Trends in Tvet.unevoc.unesco.org/fileadmin/up/2013_upub_re visiting global trends in tvet chapter9.pdf.Accessed 16 January, 2020.

Vasudeva Rao, b.s; (2012). Adult Education and rural development. Researchgate.net/publication/230739050_adult_education_and_rural_development. Accessed 27 January, 2020.

Vocational Education (2020). En.wikipedia.org/wiki/vocational education \#Australia 17/1/20.

World Bank, World Development Report (2019). The Changing Nature of work in en.wikipedia.org. Accessed 17 January, 2020.

World Development Report (2008). Agriculture for Development. Washington, D. C. The World Bank.

\section{Authors}

Dr. Mary Olufunke Adedokun had her first degree B.Ed in Adult Education (Teacher Education/English and History) in 1987. Her Master's Degree M.Ed in Adult Education (Community Development) in 1994, and Ph.D in Adult Education (Community Development) in 1998, all from the University of Ibadan, Ibadan, Oyo State, Nigeria. Her area of interests are Adult Education and Community Development.

Dr. Babajide Gabriel Agboola was born in Ibadan, Oyo State Nigeria in 1968. He had his first degree B.Ed in Adult Education (Communication and Language Arts) in 1999. His Master Degree M.Ed in Adult Education (Community Development) in 2002, and Ph.D in Adult Education (Industrial Education) in 2012, all from the University of Ibadan, Ibadan, Oyo State, Nigeria. His area of interests are Industrial Education, Open and Distance Learning and Workplace Learning.

Dr. Comfort Wuraola Adeyemo had her first degree B.Ed in Adult Education in 1996. Her Master's Degree M.Ed in Adult Education in 2006, and Ph.D in Adult Education in 2014, all from the University of Ibadan, Ibadan, Oyo State, Nigeria. Her area of interests are Adult Literacy Education, Literacy Training and Development. 